\title{
A preoperatív antibiotikus és antiszeptikus kezelés hatása a mütéti úton eltávolított alsó bölcsességfogak sebgyógyulására - prospektív randomizált vizsgálat
}

\author{
Kaposvári István dr. ${ }^{1}$ - Körmöczi Kinga dr. ${ }^{1}$ - László Zsuzsa Beáta dr. ${ }^{1}$ \\ Oberna Ferenc dr. ${ }^{2}$. Horváth Ferenc dr. ${ }^{3}$. Joób-Fancsaly Árpád dr. ${ }^{1}$ \\ ${ }^{1}$ Semmelweis Egyetem, Fogorvos-tudományi Kar, Arc-, Állcsont-, Szájsebészeti és Fogászati Klinika, Budapest \\ ${ }^{2}$ Bács-Kiskun Megyei Kórház, Arc-, Állcsont-, Szájsebészeti és Fül-Orr-Gégészeti Osztály, Kecskemét \\ ${ }^{3}$ Semmelweis Egyetem, Általános Orvostudományi Kar, Népegészségtani Intézet, Budapest
}

\begin{abstract}
Bevezetés és célkitüzés: Vizsgálatunkban az alsó bölcsességfog mútéti eltávolítását követô sebgyógyulással foglalkozunk. A posztoperatív antibiotikus terápia kiegészítéseként profilaktikusan alkalmazott antibiotikum és orális antiszeptikum hatásosságát hasonlítottuk össze. Módszer: A vizsgálatban a klinika 71 egészséges betege vett részt. A preoperatív terápiát illetően pácienseinket négy vizsgálati csoportba osztottuk: I. profilaxis amoxicillin-klavulánsavval; II. profilaxis clindamycinnel; III. profilaxis klórhexidinnel; IV. kontroll. Posztoperatívan a terápiát az I. és II. csoportban a profilaktikus antibiotikummal, a III. csoportban random választás szerint, a IV. csoportban clindamycinnel folytattuk. Vizsgáltuk az arcduzzanatot, a szájnyitási korlátozottságot, a seb gyógyulását és a posztoperatív életminőséget. Eredmények: A profilaxisban részesült betegek posztoperatív szakasza zavartalanabbnak bizonyult. Alveolitis csak a kontrollcsoportban alakult ki, két alkalommal. A kontrollcsoportban 22,2\%-ban, a clindamycinprofilaxiscsoportban 14,2\%-ban, amoxicillin-klavulánsav profilaxis esetén 10\%-ban, klórhexidin alkalmazásakor pedig 5\%-ban tapasztaltunk sebszétválást. Következtetés: Az alsó bölcsességfog mútéti eltávolítása kapcsán javasoljuk az indikált antibiotikus terápia profilaxissal való kiegészítését, amelyek közül a klórhexidin az antibiotikummal azonos hatékonyságúnak bizonyult. Orv. Hetil., 2017, 158(1), 13-19.
\end{abstract}

Kulcsszavak: alsó bölcsességfog, sebgyógyulás, antibiotikum-profilaxis, klórhexidin

Prospective randomized study regarding the effect of the preoperative antibiotic and chlorhexidine rinse on wound healing after mandibular third molar surgery

\begin{abstract}
Introduction and aim: The study compares the antibiotic prophylaxis combined with postoperative antibiotic therapy to preoperative chlorhexidine rinse combined with postoperative antibiotic therapy in preventing complications after surgical removal of a mandibular third molar. Method: 71 healthy patients in four groups were enrolled in the study: I. prophylactic dose of $2000 \mathrm{mg}$ of amoxicillin clavulanate, continued with amoxicillin clavulanate postoperatively; II. prophylactic dose of $600 \mathrm{mg}$ of clindamycin, continued with clindamycin postoperatively; III. prophylactic chlorhexidin rinsing, continued randomized amoxicillin clavulanate or clindamycin postoperatively; IV. control, with clindamycin postoperatively. Results: The pain was smaller in the prophylaxis groups. Alveolitis occurred only in the control group: 2 patients. Wound opening occurred in 22,2\% in group IV., 14,2\% in group II, $10 \%$ in group I., $5 \%$ in group III. Conclusion: We consider completing the indicated postoperative antibiotic prescription with antibiotic or antiseptic prophylaxis. Chlorhexidin prophylaxis could have the same positive effect.
\end{abstract}

Keywords: mandibular third molar, wound healing, postoperative complications, antibiotic prophylaxis, chlorhexidine 
Kaposvári, I., Körmöczi, K., László, Zs. B., Oberna, F., Horváth, F., Joób-Fancsaly, Á. [Prospective randomized study regarding the effect of the preoperative antibiotic and chlorhexidine rinse on wound healing after mandibular third molar surgery]. Orv. Hetil., 2017, 158(1), 13-19.

(Beérkezett: 2016. október 17.; elfogadva: 2016. november 10.)

A dentoalveolaris sebészet körében a bölcsességfog eltávolítása az egyik leggyakoribb beavatkozás. A bölcsességfogakkal kapcsolatban gyakran alakulnak ki különböző megbetegedések, amelyek jellemzően a fogáttörés zavarával, illetve a fogív hossza és a fogak mérete közötti diszharmóniával hozhatók összefüggésbe. A harmadik nagyőrlőkhöz köthető problémák közül leggyakrabban inflammatiós kórfolyamatok jelentkeznek. A gyulladás kialakulásának, illetve terjedésének szempontjából az alsó bölcsességfogak esetén fokozottabb a veszély az anatómiai viszonyok és a mandibula csontszerkezetéből adódóan. Az inflammatiós kórképeken kívül gyakran okozzák a szomszédos fogak károsodását, felmerül továbbá szerepük a fogazat helyzeti rendellenességeinek kialakulásában. Ciszták, valamint ritkán különböző odontogén daganatok is jelentkezhetnek a foghoz kapcsolódóan [1].

A bölcsességfogak eltávolítása történhet terápiás, illetve profilaktikus okból. Előbbi esetben az általuk okozott gyulladások, illetve a környezetükben lévő patológiás folyamatok miatt kerül sor a beavatkozásra. Profilaktikus fogeltávolítás történhet, ha fennáll a veszélye annak, hogy a beavatkozás hiányában a helytelen pozícióban lévő bölcsességfog később problémák okozójává válik. Így megelőzhető, hogy a már panaszokat okozó fogat nehezebb körülmények között (gyulladásban, korlátozott szájnyitás mellett) távolítsák el. A profilaktikus beavatkozás a klinikai és radiológiai tünetmentesség állapotában történik $[2,3]$.

A beavatkozás előtt a mútéttechnikai nehézségek, valamint a várható szövődmények felbecsüléséhez a klinikusnak segítséget nyújthat a radiológiai módszerek alapján felállított, nemzetközi szakirodalomban elfogadott kockázati osztályozás - SAC (simple, advanced, complicated) kritériumrendszer -, amely megkülönbözteti a várhatóan könnyű, közepes nehézségú, valamint nehéz bölcsességfog-eltávolításokat (1. ábra). Ennek alapja a trigonum retromolare hosszúsága, a fog okklúziós síkhoz viszonyított helyzete, valamint az impakció mértéke [4].

A bölcsességfog eltávolítása után viszonylag nagy az esély a gyulladásos komplikációk kialakulására (7-10\%) [5]. A fájdalom, az arcduzzanat és a szájnyitási korlátozottság nagymértékben meghatározza a páciens poszt-

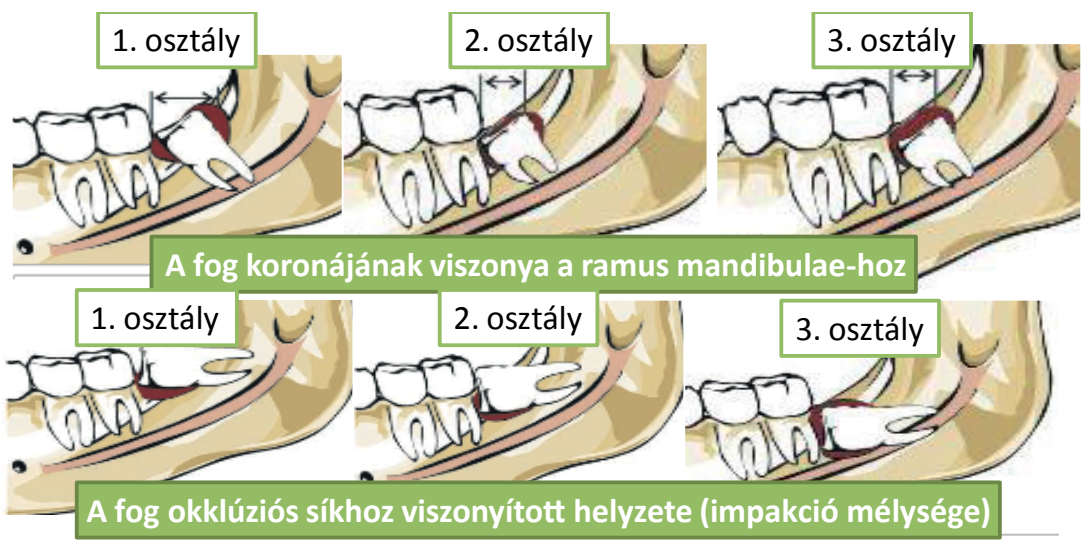

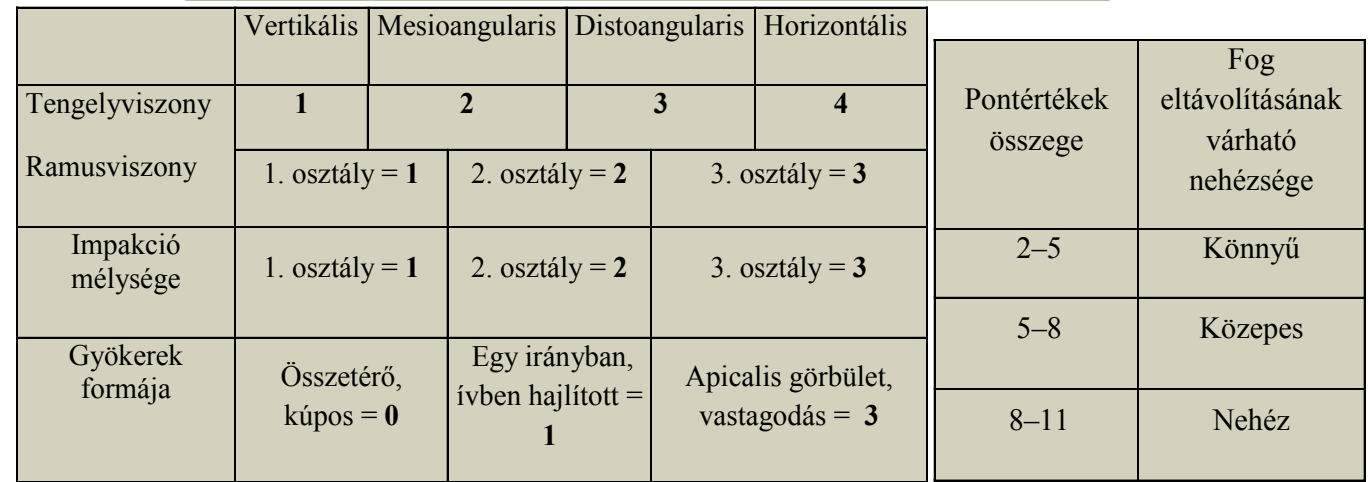

1. ábra A bölcsességfog eltávolításának várható nehézsége a radiológiai értékelés alapján (Winter, 1926 és Pell-Gregory, 1942 - klasszifikáció) 
operatív életminőségét $[6,7]$. Ismert, hogy a mütétkor jelen lévő gyulladásos folyamat (pericoronitis, parodontitis, periodontitis) a posztoperatív szövődmények komoly hajlamosító tényezője. Emellett fokozott fertőzésveszéllyel kell számolni idősebb, rosszabb szájhigiéniájú, illetve erős dohányos betegek esetében is. A mütét időtartama és bonyolultsága, a sebész tapasztalata, valamint a sebzárás formája is meghatározó a gyulladásos komplikációk kialakulásában [8-11]. A beavatkozás előtt, illetve az utókezelés során alkalmazott gyógyszerelési eljárások (például antibiotikumok, klórhexidin) csökkenthetik a szövődmények kialakulásának esélyét. A hagyományos posztoperatív felhasználás mellett az irodalomban egyre nagyobb szerepet tulajdonítanak az antibiotikumok, illetve az orális antiszeptikumok mútét előtt történő alkalmazásának a sebgyógyulás zavarának megelőzésében $[12,13]$.

A beteg általános anamnézisében szereplő egyes betegségek vagy éppen gyógyszeres terápiák befolyásolhatják a kezelés módját. Például infektív endocarditis fokozott veszélyének fennállásakor, biszfoszfonátterápia esetén, korábban fej-nyak területet érintő besugárzást követően, cukorbetegségben a beteget a fogászati, sebészeti beavatkozás során az adott állapotra kidolgozott protokoll szerinti antibiotikus profilaxisban, terápiában szükséges részesíteni $[14,15]$. Közleményünk a rizikófaktorokat hordozó páciensek fogászati-szájsebészeti ellátásával nem foglalkozik, ugyanakkor fontosnak tartjuk, hogy az orvos mindig tisztában legyen a legfrissebb, aktuálisan érvényes, ezen állapotokra vonatkozó javaslatokkal.

Az alsó bölcsességfog mútéti eltávolítása infektológiai szempontból a tiszta-kontaminált csoportba tartozik. A posztoperatív gyulladásos komplikációk többségükben bakteriális eredetüek, ezért a profilaktikusan adott, így a mütéti területen már a beavatkozás megkezdésekor jelen lévő antibiotikum a szövődmények gyakoriságát csökkentheti [12, 16-20].

A posztoperatív gyulladásokra hajlamosító tényezők fennállásakor (dohányzás, rossz szájhigiénia, 25 év feletti életkor), valamint nagyobb mennyiségű csont eltávolításával és hosszabb mútéti időtartammal járó (legalább 15 perces) beavatkozások esetén egyes szerzők az alapbetegségekkel nem rendelkező páciensek körében is javasolják a beavatkozás utáni antibiotikus terápiát és ennek profilaxissal történő bevezetését. Rövid mütétek esetén, rizikófaktorok hiányában pedig csupán a profilaxist tartják indokoltnak [21-23].

Az 1960-as években Kay vizsgálta elsőként az antibiotikum-profilaxis hatékonyságát a harmadik őrlőfog sebészetében. Vizsgálatában 1341 fogat távolított el antibiotikus kezelés nélkül, amely csoportból 325 páciensnél alakult ki ostitis alveolaris. 1620 beteg esetén a beavatkozást profilaxis mellett végezte el, ekkor csupán 50 esetben fordult elő gyulladásos szövődmény. Eredményei alapján az alveolitis előfordulásának drasztikus mértékű, 24\%-ról 3\%-ra történő csökkenéséről számolt be. Kay pericoronitises fogak eltávolítása során is elvégezte a vizsgálatot. Ebben az esetben a kontrollcsoportban 71\%ban, míg a profilaxisban részesült csoportban 8\%-ban fordult elő posztoperatív gyulladás. Az antibiotikumprofilaxisban részesült betegek a mútét előtt egy dózisban kaptak penicillint [24]. A klinikai vizsgálat hatására bölcsességfogak eltávolításakor is szélesebb körben kezdtek antibiotikus profilaxist alkalmazni [12].

Ren és mtsai 16 randomizált klinikai vizsgálat (és közel 3000 páciens) adatai alapján kívánták értékelni egészséges páciensek körében az alsó bölcsességfog eltávolítása kapcsán a mütét előtti profilaktikus, valamint a mütét utáni terápiás dózisban alkalmazott antibiotikum szerepét. A posztoperatív szövődmények megelőzésében fontosnak vélik a mútét előtt 30-90 perccel adott gyógyszert. Eredményeik alapján a profilaktikus dózis nélküli terápia kevésbé hatásos [12].

Antibiotikumok alkalmazásakor azonban mindig számolni kell az esetlegesen fellépő gastrointestinalis, valamint allergiás mellékhatásokkal. Nem szabad arról sem megfeledkezni, hogy túlzott felhasználásuk a multirezisztens kórokozók megjelenéséhez vezethet. Alkalmazásukkor ezért minden esetben mérlegelendő a kockázat és a nyereség aránya $[22,25,26]$.

Az orális antiszeptikumok csoportjába tartozó klórhexidint - széles spektrumú antimikrobiális hatásának köszönhetően - gyakran alkalmazzák a dentoalveolaris mütétek szövődményeinek megelőzésében [27-29]. Egyes szerzők szerint a mưtét előtti klórhexidinkúra az antibiotikum-profilaxishoz hasonlóan képes csökkenteni a beavatkozást követő gyulladások kialakulásának esélyét [12]. Egyértelmú előnye, hogy alkalmazásakor nem kell számolni az antibiotikumok mellékhatásaival, szisztémás mellékhatása nem ismert [27]. Field és mtsai már a '90-es években bebizonyították a preoperatív klórhexidin hatékonyságát az alsó bölcsességfog eltávolítása utáni gyulladásos szövődmények megelőzésében. Kontrollcsoportjukban 11,1\%-ban, míg a klórhexidinprofilaxisban részesült páciensek körében csupán 3,7\%-ban alakult ki alveolitis az alsó bölcsességfog eltávolítása után [30].

Vizsgálatunkban az antibiotikus és antiszeptikus profilaxis hasznosságát a hagyományos mútét utáni terápia alkalmazása mellett kívántuk értékelni.

\section{Módszer}

A vizsgálatban a Semmelweis Egyetem, Arc-, Állcsont-, Szájsebészeti és Fogászati Klinika ambulanciájának 71 betege vett részt. A 18 és 35 év közötti egészséges pácienseknél sebgyógyulást befolyásoló tényező, gyógyszerallergia, illetve egyéb gyógyszeres kezelés nem állt fenn. Betegeink nem rendelkeztek szenvedélybetegségekkel (alkohol, dohányzás, kábítószer). A részvétel feltétele volt továbbá a bölcsességfog előtti második őrlőfog egészséges állapota. A vizsgálat során impaktált alsó bölcsességfogak kerültek eltávolításra. A bevezetőben leírt kockázati osztályozás szerinti könnyen eltávolítható fo- 


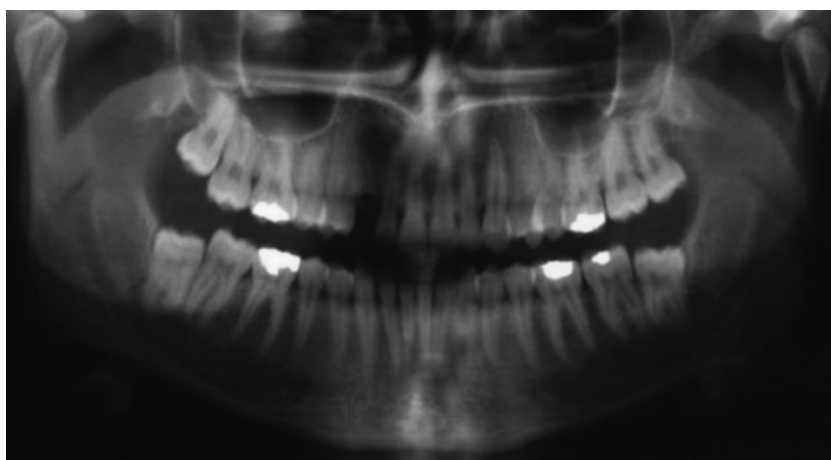

2. ábra | A könnyű mútéti csoportba tartozó vertikális állású fogak

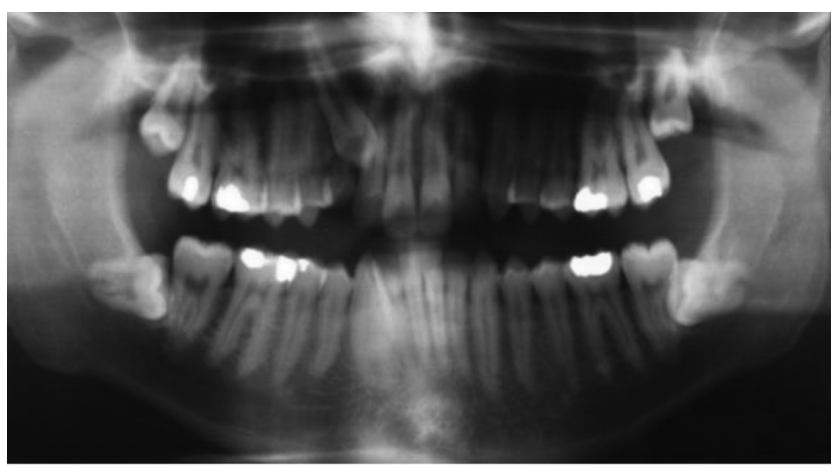

3. ábra

| A nehezített mútéti csoportba tartozó horizontális állású fogak

gak alkották könnyű (2. ábra), míg a közepes bonyolultságú fogeltávolítások képezték nehezített vizsgálati csoportunkat (3. ábra). Amennyiben a beteg megfelelt a vizsgálat kritériumainak, az orvos a konzultáció alkalmával tájékoztatta a tanulmányról. Az önkéntes résztvevők a beleegyező nyilatkozatban elfogadták, hogy adataik a vizsgálat számára felhasználhatók, valamint tudomásul vették a mútét előtti, illetve utáni tennivalókat. A kezelőorvos ezek után véletlenszerúen választotta ki a beteg sorszámát, amely meghatározta a mütét előtti kezelést. A konzultáció alkalmával a pácienseket a műtét előtti profilaxis szerint négy vizsgálati csoportba osztottuk: I. antibiotikus profilaxis és terápia amoxicillin-klavulánsavval; II. antibiotikus profilaxis és terápia clindamycinnel; III. orális antiszeptikus profilaxis 2\%-os klórhexidinnel és random választás szerint amoxicillin-klavulánsav vagy clindamycin posztoperatív antibiotikus terápia; IV. kontrollcsoport, posztoperatív clindamycinterápia. Amoxicillin-klavulánsavból $2 \times 1$ g-ot, clindamycinből 600 mg-ot vettek be az adott profilaxiscsoport tagjai a mütét előtt egy órával. Antiszeptikus profilaxis esetén a beteg a mütétet megelőző két napban, naponta három alkalommal egy percet öblögetett $10 \mathrm{ml}$ klórhexidinnel.

A mútéteket a klinikán alkalmazott protokoll szerint, azonos gyakorlattal rendelkező sebészek végezték el (K. K., J. F. Á.). A beavatkozásra minden alkalommal helyi érzéstelenítésben, L alakú lebennyel végzett feltárásból, buccalis csonteltávolítással került sor. A lebenyszél felfrissítése után a sebszéleket primer módon 3.0-s vagy 4.0-s Supramid fonallal, háromcsomós öltéssel és egy horizontális matracöltéssel egyesítették. A varratszedés a mütét utáni hetedik napon történt.

A beavatkozás után a páciensek azonos terápiában részesültek. Az orvosok fájdalomcsillapítóval (diclofenac $50 \mathrm{mg}$, maximális dózis $3 \times 1$ ) és antibiotikummal (clindamycin $300 \mathrm{mg} 4 \times 1$, amoxicillin-klavulánsav $1000 \mathrm{mg} 2 \times 1$ ) látták el a beteget.

Vizsgálatunkban számos, a sebgyógyulást jellemző paramétert rögzítettünk. Az arcduzzanat mértékét a műtétet megelőző, illetve a varratszedéskor felvett tragusmentum-távolságértékek különbségéből számítottuk. A méréseket 3.0-s fonallal végeztük, miközben a páciens feje előre tekintett, a szemei egyenes testtartás mellett a távolba néztek és az ajkai vonalszerúen érintkeztek (4. ábra). A beavatkozás előtt és azt követően egy héttel mért maximális szájnyitási értékek különbségéből kaptuk a szájnyitási korlátozottság mértékét. A maximális szájnyitást a jobb felső 1 -es és jobb alsó 1-es mesioincisalis szöglete között mértük, tolómérő segítségével (5. ábra). Az első metszéstől az utolsó öltésig tartó mütéti időtartamot feljegyeztük. Varratszedéskor vizsgáltuk a seb állapotát. Haematoma, alveolitis, genny, nyílt seb előfordulását regisztráltuk az orvosi lapon. A mútét utáni életminőséget a fogeltávolítást követő első naptól kezdve, a varratszedés napjáig kérdooív segítségével vizsgáltuk. A kérdőívben a szubjektív fájdalomérzetre (vizuális analóg skála), a nap folyamán elfogyasztott fájdalomcsillapító mennyiségére, a testhőmérsékletre, illetve az elfogyasztott étel állagára és mennyiségére vonatkozó kérdések szerepeltek. A méréseket ugyanaz a személy végezte el (K. I.).

\section{Eredmények}

Statisztikai elemzésünk során összesen 71 beteg adatait értékeltük (1. táblázat). A nemek aránya közel azonos volt (nők: $49,3 \%, \mathrm{n}=35$, férfiak: $50,7 \%, \mathrm{n}=36$ ). A vizsgált betegek átlagéletkora 24,78 év volt (standard deviáció: 6,078). A beavatkozás a könnyú mútéti csoportban átlagosan 16,3 percig, míg a nehezített csoportban 16,48 percig tartott. A véletlenszerúen kiválasztott kezelés alapján a betegeket négy csoportba soroltuk: klórhexidinnel kezeltek $(28,2 \%, \mathrm{n}=20)$, amoxicillin-klavulánsavval kezeltek $(26,8 \%, \mathrm{n}=19)$, clindamycinnel kezeltek $(19,7 \%, \mathrm{n}=14)$ és kontrollcsoport $(25,4 \%, \mathrm{n}=18)$. Szövődményként haematoma $8,5 \%$-ban $(n=6)$, alveolitis $2,8 \%$-ban $(\mathrm{n}=2)$, nyílt seb $14,1 \%$-ban $(\mathrm{n}=10)$ volt megfigyelhető, genny pedig nem fordult elő.

A kezelés és a szövődmények közötti kapcsolat vizsgálatát kereszttáblás elemzésekkel végeztük el. Szignifikáns különbséget nem találtunk a különböző profilaxisban részesült csoportok között, ugyanakkor a kontrollcsoportok esetén gyakrabban alakult ki gyulladásos szövődmény. Alveolitis csak a könnyû mütétek kontrollcsoportjában fordult elő, két alkalommal. A seb a profilaktikus kezelésben nem részesült páciensek kö- 


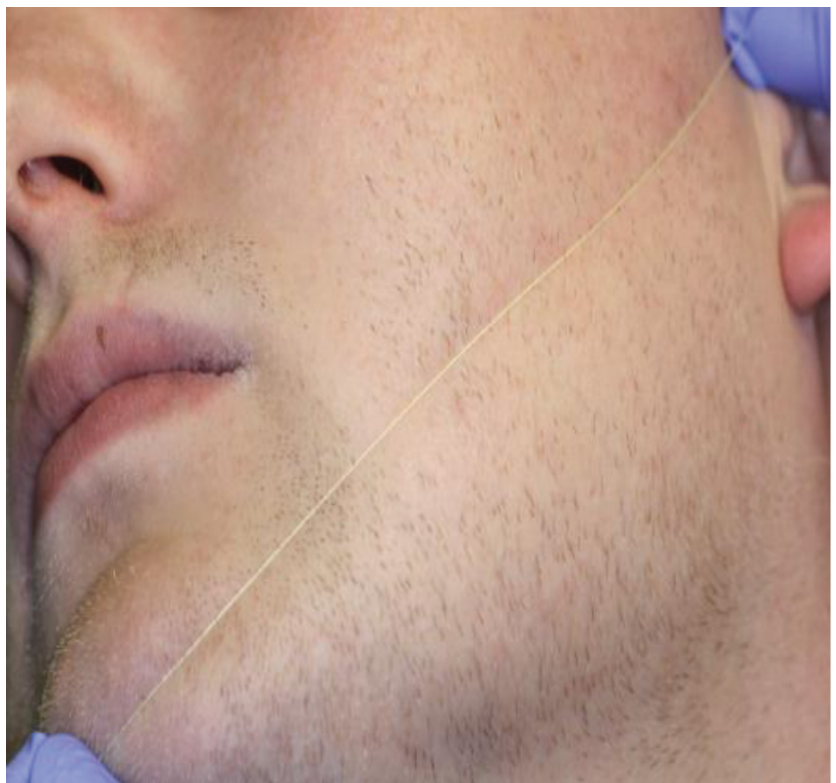

4. ábra

| A tragus-mentum távolság mérése

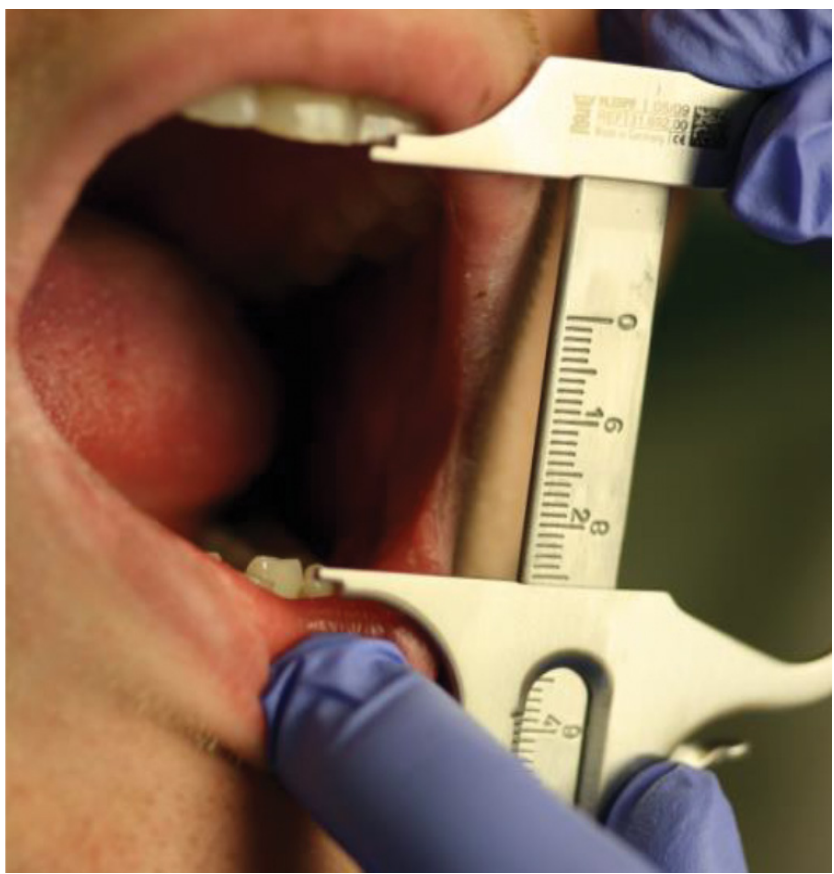

5. ábra

| A maximális szájnyitás mérése

1. táblázat | Esetszámok

\begin{tabular}{|c|c|c|}
\hline Profilaxis Mütéti csoport & $\begin{array}{l}\text { Könnyű mütéti } \\
\text { csoport }\end{array}$ & $\begin{array}{l}\text { Nehezített mütéti } \\
\text { csoport }\end{array}$ \\
\hline I. amoxicillin-klavulánsav & 10 & 9 \\
\hline II. clindamycin & 7 & 7 \\
\hline III. klórhexidin & 9 & 11 \\
\hline IV. kontroll & 8 & 10 \\
\hline
\end{tabular}

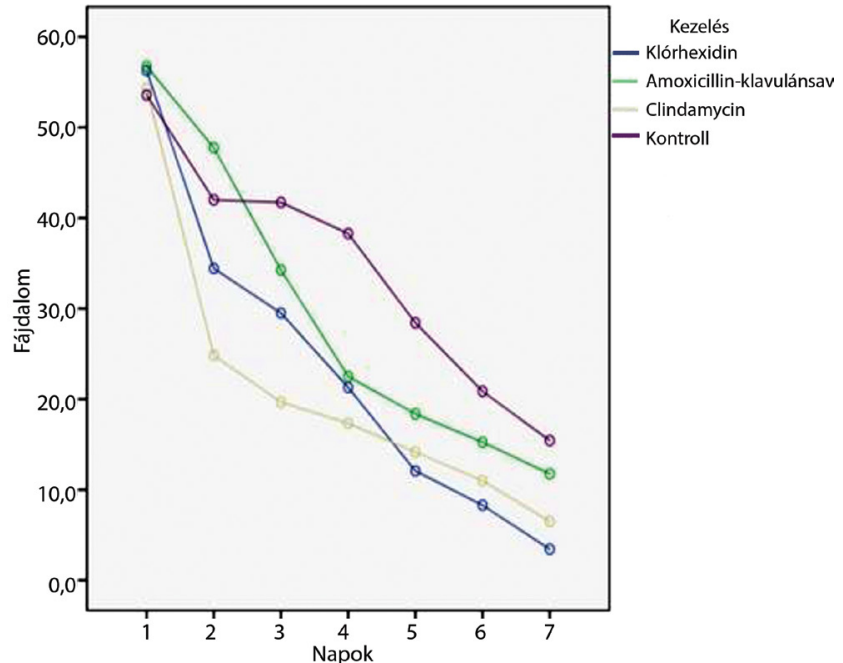

6. ábra A fájdalom változása (vizuális analóg skála alapján)

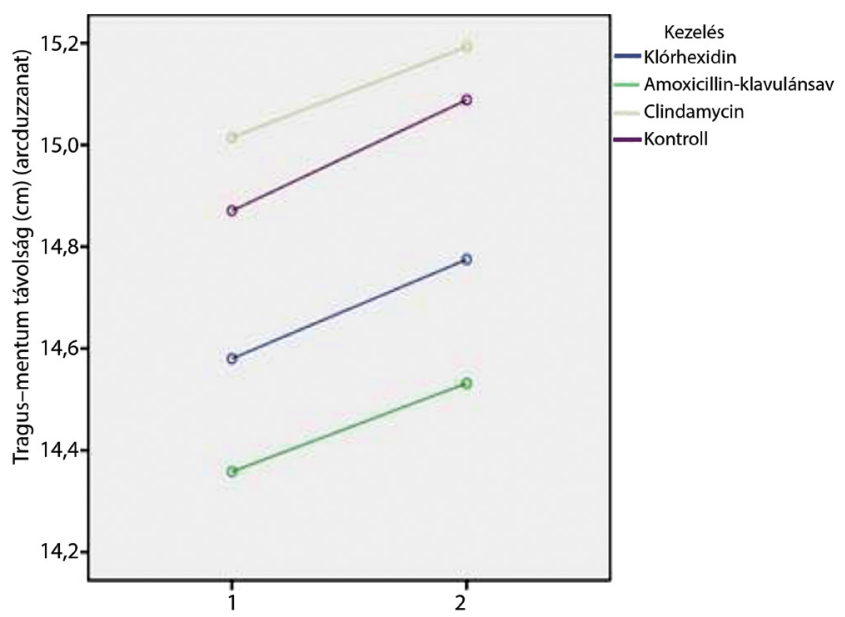

7. ábra $\mid$ A tragus-mentum távolság mértéke a mútét előtti (1), illetve utáni (2) méréskor. Klórhexidin profilaxis esetén a legkisebb a vonal meredeksége, azaz a duzzanat

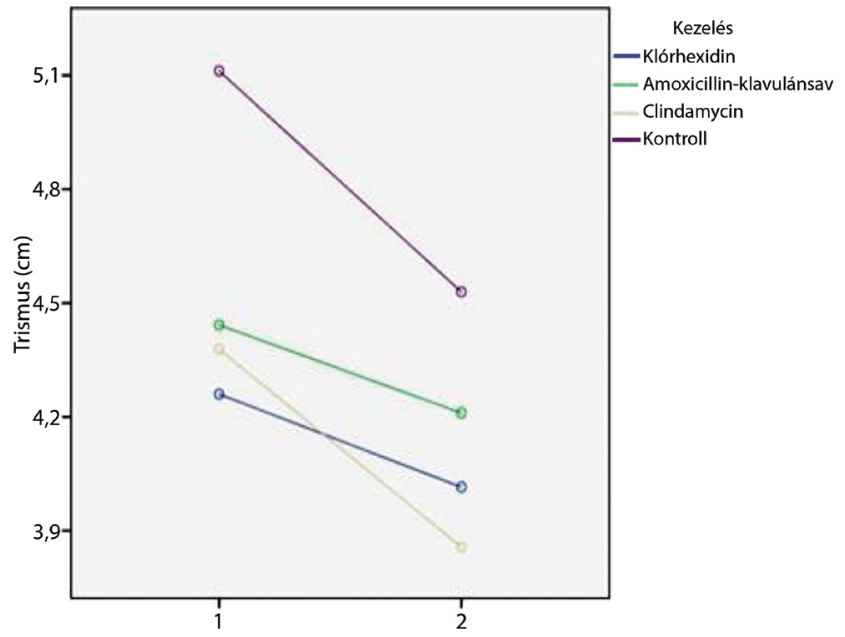

8. ábra $\mid$ A szájnyitás mértékének változása a mútét előtti (1), illetve utáni (2) méréskor. Klórhexidin és amoxicillin-klavulánsav profilaxis esetén a legkisebb varratszedéskor a szájnyitási korlátozottság mértéke 
rében gyakrabban vált szét. Varratszedéskor sebszétválást könnyú mútéteknél összesen négy alkalommal regisztráltunk, a kontrollcsoportban két esetben, amoxicillinklavulánsav és clindamycinprofilaxis mellett pedig egyegy esetben. A nehezített mútéteknél összesen öt alkalommal, a kontrollcsoportban két esetben, clindamycin-, amoxicillin-klavulánsav, valamint klórhexidinprofilaxis esetén pedig egy-egy esetben fordult elő ez a szövődmény. A páciensek által kitöltött kérdőívek adatainak, valamint az ödéma és a trismus kezeléssel történő összefüggésének elemzésére 'Split-Plot' ANOVA-t végeztünk. A mútétet követő harmadik és negyedik napon az antibiotikum- vagy klórhexidinprofilaxisban részesült betegek kisebb fájdalomérzetet tapasztaltak a kontrollcsoporthoz képest $(\mathrm{p}>0,05)$. A nehezített mútétek elemzése során a valamely profilaxisban részesült betegek szubjektív fájdalomérzete a gyógyulás során enyhébbnek bizonyult, míg a könnyú mútéti csoportnál a klórhexidinprofilaxis mutatkozott a legelőnyösebbnek $(p>0,05)$ (6. ábra). A posztoperatív szakaszban mind a könnyú, mind pedig a nehezített mútéti csoportban a klórhexidinprofilaxisban részesült páciensek vették be a legkevesebb fájdalomcsillapítót (2. táblázat). Az ödéma és a trismus mértéke nem mutatott szignifikáns eltérést az egyes profilaxiscsoportok között, ugyanakkor a nehezített mútéteknél az antiszeptikus kúrában részesült betegek körében volt a legkisebb az ödéma mértéke (7. ábra). A szájnyitási korlátozottság tekintetében a könnyebb fogeltávolítások során a klórhexidinprofilaxis, míg a nehezebb mútéteknél az amoxicillin-klavulánsav profilaxis mutatkozott előnyösebbnek (8. ábra).

\section{Megbeszélés}

Vizsgálatunk során a beavatkozás előtt kezelésben nem részesült páciensek körében, megegyező szájhigiénia és mútéti időtartam esetén gyakoribb szövődményeket és lassabb gyógyulási folyamatot tapasztaltunk. A valamely profilaxisban részesült betegek posztoperatív fájdalomérzete, arcduzzanata és szájnyitási korlátozottsága kisebbnek bizonyult a kontrollcsoporthoz képest $(p>0,05)$. A kontrollcsoportban $22,2 \%$-ban, a clindamycinprofilaxis-csoportban 14,2\%-ban, amoxicillin-klavulánsav profilaxis esetén 10\%-ban, klórhexidin alkalmazásakor pedig 5\%-ban tapasztaltunk sebszétválást. Két esetben alakult ki alveolitis: a kontrollpáciensek körében.

2. táblázat |A varratszedésig bevett fájdalomcsillapító átlagos mennyisége (darab)

\begin{tabular}{|c|c|c|}
\hline Profilaxis Mútéti csoport & $\begin{array}{l}\text { Könnyú mútéti } \\
\text { csoport }\end{array}$ & $\begin{array}{l}\text { Nehezített mútéti } \\
\text { csoport }\end{array}$ \\
\hline I. amoxicillin-klavulánsav & 5,5 & 8,2 \\
\hline II. clindamycin & 6,2 & 7,1 \\
\hline III. klórhexidin & 4,0 & 5,21 \\
\hline IV. kontroll & 6,5 & 8,3 \\
\hline
\end{tabular}

A fentiek alapján a klórhexidin- és az antibiotikumprofilaxis előnyősnek bizonyult. A klórhexidin alkalmazását elsősorban a szisztémás mellékhatások hiánya, másodrészt az észlelt enyhébb posztoperatív fájdalom preferálja. Az antiszeptikus, mellékhatások nélküli kezelés igazi előnye azonban a dentoalveolaris sebészetben, bölcsességfog eltávolításakor (elsősorban komplikált esetekben) rutinszerúen elterjedt antibiotikus terápia kiváltása lehet. Ehhez azonban az indikációs kör pontos meghatározásával, megfelelően tervezett újabb vizsgálat lefolytatása szükséges.

Anyagi támogatás: A közlemény megírása anyagi támogatásban nem részesült.

Szerzői munkamegosztás: K. K., J.-F. Á., L. Zs. B., K. I.: A vizsgálat lefolytatása. O. F.: A hipotézis kidolgozása. H. F., K. I.: Statisztikai elemzések. A cikk végleges változatát valamennyi szerző elolvasta és jóváhagyta.

Érdekeltségek: A szerzőknek nincsenek érdekeltségeik.

\section{Irodalom}

[1] Szücs, A.: The pathology and symptomatology of wisdoom teeth. In: Joób-Fancsaly, Á. (ed.): The role of wisdom teeth in dentistry. [A bölcsességfogak által okozott betegségek kór- és tünettana. In: Joób-Fancsaly, Á. (szerk.): A bölcsességfogak szerepe a fogászat különböző szakterületein.] Semmelweis Kiadó, Budapest, 2010, 30-45. [Hungarian]

[2] Joób-Fancsaly, Á.: Indication and contraindication of wisdoom tooth removal. In: Joób-Fancsaly, Á. (ed.): The role of wisdom teeth in dentistry. [A bölcsességfogak eltávolításának indikációi és kontraindikációi. In: Joób-Fancsaly, Á. (szerk.): A bölcsességfogak szerepe a fogászat különböző szakterületein.] Semmelweis Kiadó, Budapest, 2010, 73-77. [Hungarian]

[3] Divinyi, T.: The management of partially erupted and unerupted teeth (impacted and retained teeth). In: Szabó, Gy. (ed.): Oral and maxillofacial surgery. [Áttörésben visszamaradt fogak sebészi ellátása (impaktált, retineált fogak). In: Szabó, Gy. (szerk.): Szájsebészet, maxillofacialis sebészet.] Semmelweis Kiadó, Budapest, 2001, 69-78. [Hungarian]

[4] Pell, G. J., Gregory, G. T.: Impacted mandibular third molars: classification and modified technique for removal. Dent. Digest., 1933, 39(9), 330-338.

[5] Baqain, Z. H.: Avoiding morbidities in third molar surgery: current practice. Hard Tissue, 2012, $1(1), 10$.

[6] McGrath, C., Comfort, M. B., Lo, E. C., et al.: Changes in life quality following third molar surgery - the immediate postoperative period. Br. Dent. J., 2003, 194(5), 265-268.

[7] Deepti, C., Rehan, H. S., Mehra, P.: Changes in quality of life after surgical removal of impacted mandibular third molar teeth. J. Maxillofac. Oral Surg., 2009, 8(3), 257-260.

[8] Al-Khateeb, T. L., El-Marsafi, A. I., Butler, N. P.: The relationship between the indications for the surgical removal of impacted third molars and the incidence of alveolar osteitis. Oral Maxillofac. Surg., 1991, 49(2), 141-145.

[9] Gary, G.: Clinical management of acute orofacial infections. [A fej-nyak régió akut fertőzéseinek kezelése.] Magyar Fogorvos, 2015, 24(3), 124-135. [Hungarian]

[10] Joób-Fancsaly, Á.: Complications of wisdom teeth removal. In: Joób-Fancsaly, Á. (ed.): The role of wisdom teeth in dentistry. [A bölcsességfogak sebészetének szövődményei, komplikációi. 
In: Joób-Fancsaly, Á. (szerk.): A bölcsességfogak szerepe a fogászat különböző szakterületein.] Semmelweis Kiadó, Budapest, 2010, 129-138. [Hungarian]

[11] Vlcek, D., Razavi, A., Kuttenberger, J. J.: Antibiotics in third molar surgery. Swiss Dent. J., 2014, 124(3), 294-302.

[12] Ren, Y. F., Malmstrom, H. S.: Effectiveness of antibiotic prophylaxis in third molar surgery: a meta-analysis of randomized controlled clinical trials. J. Oral Maxillofac. Surg., 2007, 65(10), 1909-1921

[13] Yengopal, V., Mickenautsch, S.: Chlorhexidine for the prevention of alveolar osteitis. Int. J. Oral Maxillofac. Surg., 2012, $41(10)$ 1253-1264.

[14] Nagy, G., Gera, I., Fejérdy, P.: The dental treatment plan. In: Nagy, G., Fejérdy, P. (eds.): Oraldiagnostic. 2nd ed. [A fogorvosi kezelési tervrő́l általában. In: Nagy, G., Fejérdy, P. (szerk.): Orális diagnosztika. 2. kiadás.] Medicina Könyvkiadó, Budapest, 2011, 231-246. [Hungarian]

[15] Ludwig, E.: Basic of antibiotic management. Oral cavity, head and neck infections. In: Tulassay, Zs., Békési, G., Rácz, K. (eds.): Basic-internal medicine for dentists. [Az antibakteriális kezelés alapjai. A szájüreg, nyaki régió fontosabb fertőzései. In: Tulassay, Zs., Békési, G., Rácz, K. (szerk.): A belgyógyászat alapjai fogorvosok számára.] Medicina Könyvkiadó, Budapest, 2014, 361374. [Hungarian]

[16] Arteagoitia, I., Diez, A., Barbier, L., et al.: Efficacy of amoxicillin/clavulanic acid in preventing infectious and inflammatory complications following impacted mandibular third molar extraction. Oral Surg. Oral Med. Oral Pathol. Oral Radiol. Endod., 2005, 100(1), ell-el8.

[17] De Lalla, F.: Perioperative antibiotic prophylaxis: A critical review. Surg. Infect., 2006, 7(Suppl. 2), S37-S39.

[18] Monaco, G., Tavernese, L., Agostini, R., et al.: Evaluation of antibiotic prophylaxis in reducing postoperative infection after mandibular third molar extraction in young patients. J. Oral Maxillofac. Surg., 2009, 67(7), 1467-1472.

[19] Prinz, Gy.: Principles of perioperativ antibiotic prophylaxis [A perioperatív antibiotikum-profilaxis alapelvei.] Nőgyógyászati Onkológia, 1996, 1(3), 293-295. [Hungarian]

[20] Robbins, S.: Histological regeneration, wound healing, and fibrosis. In: Robbins, S.: Basic-Pathology. [Szöveti regeneráció, sebgyógyulás és fibrosis. In: Robbins, S.: A patológia alapjai.] Medicina Kiadó, Budapest, 2009, 67-89. [Hungarian]
[21] Benediktsdóttir, I. S., Wenzel, A., Petersen, J. K., et al.: Mandibular third molar removal: Risk indicators for extended operation time, postoperative pain, and complications. Oral Surg. Oral Med. Oral Pathol. Oral Radiol. Endodont., 2004, 97(4), 438446.

[22] Oomens, M. A., Forouzanfar, T.: Antibiotic prophylaxis in third molar surgery: a review. Oral Surg. Oral Med. Oral Pathol. Oral Radiol., 2012, 114(6), e5-e12.

[23] Rodrigues, W. C., Okamoto, R., Pellizzer, E. P., et al.: Antibiotic prophylaxis for third molar extraction in healthy patients: Current scientific evidence. Quintessence Int., 2015, 46(2), 149161.

[24] Kay, L. W.: Investigations into the nature of pericoronitis - II. Br. J. Oral Maxifollac. Surg., 1966, 4, 52-78.

[25] Ludwig, E., Bánhegyi, D., Király, K., et al.: Antimicrobial chemotherapy. In: Gyires, K., Fürst, Zs. (ed.): Basics of pharmacology. [Antimikrobás kemoterápia. In: Gyires, K., Fürst, Zs. (szerk.): A farmakológia alapjai.] Medicina Könyvkiadó, Budapest, 2011, 817-911. [Hungarian]

[26] Kelentey, B.: Racional antibiotic management of dental infec tions. [Racionális antibiotikum-alkalmazás fogászati infekcióknál.] Magyar Fogorv., 2012, 21(5), 238-244. [Hungarian]

[27] Gera, I.: The prevention of parodontitis. In: Nyárasdy, I., Bánóczy, J. (eds).: Preventiv dentistry. [A fogágybetegség megelőzo"sének módszerei. In: Nyárasdy, I., Bánóczy, J. (szerk.): Preventív fogászat.] Medicina Könyvkiadó, Budapest, 2009, 217-263. [Hungarian]

[28] Berwick, J. E., Lessin, M. E.: Effects of a chlorhexidine gluconate oral rinse on the incidence of alveolar osteitis in mandibular third molar surgery. J. Oral Maxillofac. Surg., 1990, 48(5), 444-448.

[29] Vlcek, D., Razavi, A., Kuttenberger, J. J.: Wound management and the use of mouth rinse in mandibular third molar surgery. Swiss Dent. J., 2015, 125(10), 1085-1093.

[30] Field, E. A., Speechley, J. A., Rotter, E., et al.: Dry socket incidence compared after a 12 -year interval. Br. J. Oral Maxillofac. Surg., $1985,23(6), 419-427$.

(Kaposvári István dr., Budapest, Temesvári u. 43/B, 1221 e-mail: kaposvari.isti@gmail.com)

\section{A rendezvények és kongresszusok híranyagának leadása}

a lap megjelenése előtt legalább 40 nappal lehetséges, a 6 hetes nyomdai átfutás miatt. Kérjük megrendelőink szíves megértését.

A híranyagokat a következő címre kérjük:

Orvosi Hetilap titkársága: Budai.Edit@akkrt.hu

Akadémiai Kiadó Zrt. 